\title{
Concentration of skim milk by reverse osmosis: characterization and flow decline modelling
}

\section{Concentração de leite desnatado por osmose inversa: caracterização e modelagem de declínio fluxo}

\author{
Giordana Demaman Arend ${ }^{1}$, Suelen Muhl Castoldi², Katia Rezzadori3* (1), \\ Lenilton Santos Soares ${ }^{1}$, Vandré Barbosa Brião ${ }^{2}$
}

${ }^{1}$ Universidade Federal de Santa Catarina (UFSC), Departamento de Engenharia Química e Engenharia de Alimentos, Florianópolis/SC - Brasil

${ }^{2}$ Universidade de Passo Fundo (UPF), Departamento de Engenharia de Alimentos, Passo Fundo/RS - Brasil

${ }^{3}$ Universidade Federal do Rio Grande do Sul (UFRGS), Instituto de Ciência e Tecnologia de Alimentos,

Departamento de Tecnologia de Alimentos, Porto Alegre/RS - Brasil

*Corresponding Author: Katia Rezzadori, Universidade Federal do Rio Grande do Sul (UFRGS), Instituto de Ciência e Tecnologia de Alimentos, Departamento de Tecnologia de Alimentos, Av. Bento Gonçalves, 9500,

Campus do Vale, Prédio 43.212, CEP: 91501-970, Porto Alegre/RS - Brasil, e-mail: katia.rezzadori@ufrgs.br

Cite as: Arend, G. D., Castoldi, S. M., Rezzadori, K., Soares, L. S., \& Brião, V. B. (2019). Concentration of skim milk by reverse osmosis: characterization and flow decline modelling. Brazilian Journal of Food Technology, 22, e2019028. https://doi.org/10.1590/1981-6723.02819

\begin{abstract}
In this paper the physicochemical characteristics and the flow decline occurring during the reverse osmosis of skim milk, were analysed. The flow decline was evaluated using the resistances in series, the blocked pore models and a second conjugated model that combined the blocked pores with the development of a filter cake. The main resistance found was the concentration by polarization, which was mainly influenced by the complete blocking of the pores. The conjugated model was capable of predicting the flow decline of the process. With respect to the physicochemical properties, more than $98 \%$ of the lactose, protein, oils and fats were retained, demonstrating the efficiency of the process.
\end{abstract}

Keywords: Skim milk; Pore blocking; Mathematical model; Hermia model; Combined model; Flow decline.

\section{Resumo}

Neste trabalho, as características físico-químicas e o declínio de fluxo durante o processo de osmose inversa foram analisados. O declínio de fluxo foi avaliado utilizando-se resistências em série, os modelos de bloqueio de poro e um segundo modelo conjugado, que consiste na combinação de resistências decorrentes dos bloqueios de poro e do desenvolvimento da torta de filtração. A principal resistência encontrada foi a concentração por polarização, sendo que o processo foi principalmente influenciado pelo bloqueio completo de poros. O modelo conjugado foi capaz de predizer o declínio de fluxo do processo. Em relação às propriedades físico-químicas, a lactose, a proteína e os óleos e gorduras apresentaram uma retenção acima de $98 \%$, demonstrando a eficiência do processo.

Palavras-chave: Leite desnatado; Bloqueio de poros; Modelagem matemática; Modelo de Hermia; Modelo combinado; Declínio de fluxo. 


\section{Introduction}

One important unit operation widely used in dairy processes is the $r$ concentration of skim milk by evaporation, due to the need to pre-concentrate skim milk to a total solids content of around $40-50 \%$ (Liu et al., 2012). Although it is well known that the concentration of the milk reduces its water activity, it also increases its dependence on the temperature, or in other words, more energy is required for water removal. However, it is known that the use of evaporation to reduce the volume can damage the milk proteins and accelerate the Maillard Reaction (Mendes et al., 2012).

In this context, the use of membrane separation processes is an alternative, since they present some advantages for dairy products such as reduced energy requirements, negligible denaturation of the product and retention of the aroma and flavour (Jamal et al., 2004). Meyer et al. (2015) reported that the energy consumption for evaporation could be reduced by removing as much water as possible with a membrane process. Thus the use of membrane technology, such as reverse osmosis, can be promising as a preconcentration process.

Concentrated milk obtained by membrane concentration can be used in several food formulations, such as yoghurts, ice cream, bakery products or some meals, by replacing the use of milk powder, since this material is expensive and requires intensive energy for drying. Depping et al. (2017) compared evaporation and membrane processes and observed that the use of concentrates obtained by membranes was more environmentally friendly and could save up to $35 \%$ of cumulative energy demand (Depping et al., 2017).

Daufin et al. (2001) reported that around $40 \%$ of the total amount of membranes produced were used in the dairy industry, ultrafiltration (UF) and reverse osmosis (OR) being the filtration types used with greater frequency. Balde \& Aïder (2017) studied the concentration of skim milk by reverse osmosis, cryoconcentration and vacuum-assisted evaporation. The results showed a darker colour for the milk obtained by evaporation, besides which Wenten \& Khoiruddin (2016) reported that milk could be concentrated to remove $70 \%$ of the water content, with no damage to the nutritional content. Also, Tamime \& Robinson (2007) recommended the use of reverse osmosis for the production of yoghurt and milk powder, as an alternative or complementation for vacuum concentration.

Although membrane processes present several advantages, the flow reduction during filtration still represents a limiting factor for the industrial process, requiring research. Maintenance of the permeate flow and the quality of the concentrate require periodic cleaning and maintenance, which increases the costs and process time and can damage the membrane (Said et al., 2015).

According to De Bruijn et al. (2002), the flow decline is occasioned by the rejection of solutes by the membrane. The increase in solute concentration next to the membrane surface causes a sharp decline during the initial minutes of the process due to concentration by polarization, followed by a gradual decline due to the formation of a filter cake. This behaviour requires a complete understanding of the flow decline in order to scale up the system. Furthermore, knowledge of the blocking mechanisms is important since it can provide guidance for the cleaning methods (Said et al., 2015).

Given this background, a complete study of reverse osmosis is highly important, since the flow decline can influence the whole process, even the quality of the concentrate. To the best of the authors' knowledge, no studies have yet been published with a complete study of the physicochemical characteristics of the final concentrate and of the flow decline. So the aim of this study was to evaluate the concentration of skim milk by reverse osmosis, evaluating all the fractions obtained, and study the flow decline by several mathematical models in order to obtain a complete understanding. 


\section{Material and methods}

\subsection{Reverse osmosis process}

Pasteurized skim milk was obtained from the local market (Passo Fundo, Brazil) and used as feed for the concentration process. The runs were carried out with a polyamide membrane with a spiral configuration (Koch Membrane, $3838 \mathrm{HR}-\mathrm{VYV}$ ) and filtration area of $5.7 \mathrm{~m}^{2}$. Figure 1 shows a schematic representation of the equipment used for concentration and the operational conditions of $20 \pm 5{ }^{\circ} \mathrm{C}$ and 20 bar were previously determined by the membrane permeability with different combinations of temperature and pressure.

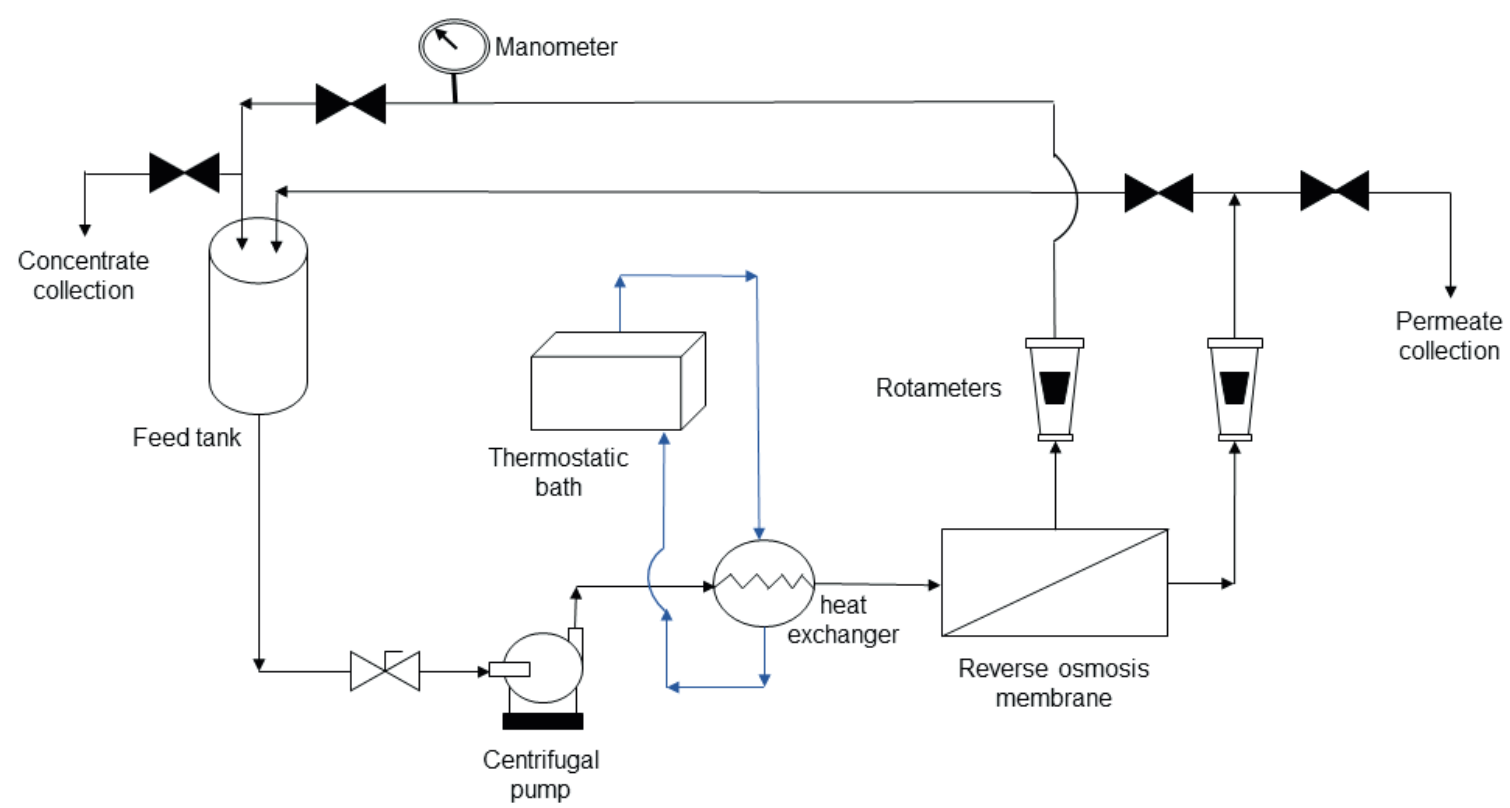

Figure 1. Schematic representation of the equipment for the concentration of skim milk with a reverse osmosis membrane. Source: Adapted from Brião \& Tavares (2012a).

The experiment was carried out using an open system and a volume reduction factor (VRF) of 3.96 L of skim milk was fed in and $64 \mathrm{~L}$ of permeate was removed. The permeate flow $(\mathrm{J})$ was measured throughout the process. Equation 1 was used to determine the flow.

$\mathrm{J}=\frac{\mathrm{Q}}{\mathrm{A}} \quad\left(\mathrm{L} \mathrm{h}^{-1} \mathrm{~m}^{-2}\right)$

\subsection{Physicochemical properties}

The soluble solids of the feed, permeate and retentate were measured using a refractometer. The lactose concentration was determined using the dinitrosalicylic acid (DNS) method according to Miller (1959) and the protein concentration was determined by the Kjeldahl method according to Association of Official Analytical Chemists (1990). The lipid concentration was determined using the Gerber method according to Instituto Adolfo Lutz (2008), and all the analyses were carried out in triplicate. 


\subsection{Resistances to flow decline}

Different resistances can appear throughout the process when a complex solution is used as the feed solution. The sum of these resistances is represented by a total resistance $R_{t}\left(m^{-1}\right)$, which is considered as the sum of all the system resistances (Equation 2).

$\mathrm{R}_{\mathrm{t}}=\mathrm{R}_{\mathrm{m}}+\mathrm{R}_{\mathrm{r}}+\mathrm{R}_{\mathrm{ir}}$

The $R_{t}$ was calculated according to Equation 3, considering the final permeate flow $J_{\mathrm{f}}\left(\mathrm{L} \mathrm{h}^{-1} \mathrm{~m}^{-2}\right)$. The permeate viscosity was considered to be similar to that of water $\mu_{\mathrm{w}}\left(\mathrm{mPa} \mathrm{s}^{-1}\right)$ and the experimental pressure $\mathrm{P}(\mathrm{Pa})$ was controlled.

$R_{t}=\frac{P}{\mu_{w} J_{f}}$

The membrane resistance $\mathrm{R}_{\mathrm{m}}\left(\mathrm{m}^{-1}\right)$ was obtained from Equation 4 by permeating pure water through the RO membrane. The viscosity of water $\mu_{\mathrm{W}}\left(\mathrm{mPa} \mathrm{s}^{-1}\right)$ and the permeate flow $\mathrm{J}_{\mathrm{W}}\left(\mathrm{L} \mathrm{h}^{-1} \mathrm{~m}^{-2}\right)$ were considered before the process with the skim milk.

$\mathrm{R}_{\mathrm{m}}=\frac{\mathrm{P}}{\mu_{\mathrm{w}} \mathrm{J}_{\mathrm{w}}}$

The irreversible fouling resistance $\mathrm{R}_{\text {ir }}\left(\mathrm{m}^{-1}\right)$ was obtained after filtration of the skim milk. The skim milk was removed, and pure water was fed into the system to obtain the water permeate flow $J_{\mathrm{Wf}}\left(\mathrm{L} \mathrm{h}^{-1} \mathrm{~m}^{-2}\right)$. Equation 5 was used to calculate the $\mathrm{R}_{\text {ir. }}$.

$\mathrm{R}_{\text {ir }}=\left(\frac{\mathrm{P}}{\mu_{\mathrm{w}} \mathrm{J}_{\mathrm{wf}}}\right)-\mathrm{R}_{\mathrm{m}}$

Since $R \mathrm{t}\left(\mathrm{m}^{-1}\right)$ is the sum of all the resistances, the reversible resistance $R r\left(\mathrm{~m}^{-1}\right)$ was obtained by difference, as shown in Equation 6.

$\mathrm{R}_{\mathrm{r}}=\mathrm{R}_{\mathrm{t}}-\mathrm{R}_{\mathrm{m}}-\mathrm{R}_{\mathrm{ir}}$

\subsection{Flow decline modelling}

The model suggested by Hermia (1982) and adapted by Field et al. (1995) for cross-flow filtration was used. Equation 7 shows the mathematical model.

$-\frac{\mathrm{dJ}}{\mathrm{dt}}\left(\mathrm{J}^{\mathrm{n}-2}\right)=\mathrm{k}\left(\mathrm{J}-\mathrm{J}^{*}\right)$

For the present work the $\mathrm{n}$ values used were $\mathrm{n}=2$ for complete pore blocking, $\mathrm{n}=1$ for intermediate pore blocking and $\mathrm{n}=0$ for the filter cake layer. The $\mathrm{n}$ values for standard pore blocking according to Corbatón-Báguena et al. (2015) were not considered for the present work, since it is well known there are no particles smaller than the pore of an osmosis membrane.

A second model suggested by Ho \& Zydney (2000) (Equation 8), was used to evaluate the combined effect of pore blockage and the filter cake layer. This model assumes that a uniform deposition of the particles occurs on the membrane surface.

$\mathrm{Q}=\mathrm{Q}_{0}\left[\exp \left(-\frac{\alpha \Delta \mathrm{PC}}{\mu \mathrm{R}_{\mathrm{m}}} \mathrm{t}\right)+\frac{\mathrm{R}_{\mathrm{m}}}{\mathrm{R}_{\mathrm{m}}+\mathrm{R}_{\mathrm{p}}} \mathrm{X}\left(1-\exp \left(-\frac{\alpha \Delta \mathrm{PC}}{\mu \mathrm{R}_{\mathrm{m}}} \mathrm{t}\right)\right)\right]$

For this model some important parameters were added, such as the fraction of total protein that contributed to the growth of the deposit (f'), the pore blockage parameter $(\alpha)$ and the bulk protein concentration $(C)$, enabling more accurate modelling. In addition, the main equation (Equation 8) was divided into two terms, the first term being equivalent to the classical pore blockage model (Hermia), giving a simple exponential 
decay in the volumetric flow rate. The second term controls the permeate flow in the long-term filtration process, and is proportional to the ratio of the membrane resistance and the total resistance (Ho \& Zydney, 2000). Maximum resistance occurs over the region where the deposit has continued to grow throughout filtration.

Equation 9 was used to evaluate the maximum value of the resistance of the protein layer (Rp), considering the entire fouled surface of the membrane.

$R_{p}=\left(R_{m}+R_{p 0}\right) \sqrt{1+\frac{2 f^{\prime} R^{\prime} \Delta P C}{\mu\left(R_{m}+R_{p 0}\right)^{2}}} t-R_{m}$

A computer routine for MATLAB (R2013a, MathWorks Inc, MA, USA) was developed for all equations by adjusting the equation to the experimental data using the nlinfit function, which is a nonlinear regression method. Values were obtained for all the parameters and for the determination coefficient $\left(\mathrm{R}^{2}\right)$.

\subsection{Data analysis}

The data analysis was carried out using the Statistica software, and the results expressed as the mean \pm standard deviation (SD) of triplicates. ANOVA and the Tukey test with $5 \%$ of significance were used to verify significant differences.

\section{Results and discussion}

\subsection{Concentration of the skim milk}

Table 1 shows the protein, lactose and lipid concentrations after the concentration process with VRF $=3$.

Table 1. Protein, lactose and lipid concentrations and their retentions ( $\% \mathrm{R})$ in the concentration of skim milk by reverse osmosis at $20^{\circ} \mathrm{C}$ and 20 bar.

\begin{tabular}{ccccccc}
\hline Sample & Protein (\%) & \% R & Lactose (\%) & \% R & Lipid (\%) & \% R \\
\hline Skim milk & 2.99 & & 6.410 & & 0.150 & \\
Concentrate & 5.19 & 100 & 12.390 & 99.97 & 0.250 & 98.47 \\
Permeate & 0.00 & & 0.003 & & 0.004 & \\
\hline
\end{tabular}

Table 1 shows a concentration of the protein content of around 1.7 fold and no detection of this component in the permeate. According to Fennema (2000), the milk proteins have a molecular diameter of around $6 \mathrm{~nm}$, being retained by the membrane, corroborating the retention value of $100 \%$.

The concentration expected for the protein was around 3 fold higher than that of the skim milk fed to the process, since the VRF used was 3, but the concentration factor obtained was only around 1.5 fold. This behaviour may have been due to the establishment of fouling. It is well known that during the reverse osmosis process the proteins are active agents of membrane fouling, adhering on the membrane surface and reducing their concentration in the fraction retained. This behaviour can be also confirmed in Figure 2, where the main resistance is the reversible resistance, which is related to the retention and deposition of this solid on the membrane surface, resulting in a higher concentration of this solute on the membrane surface in comparison with the bulk solution (Mello, 2012). 


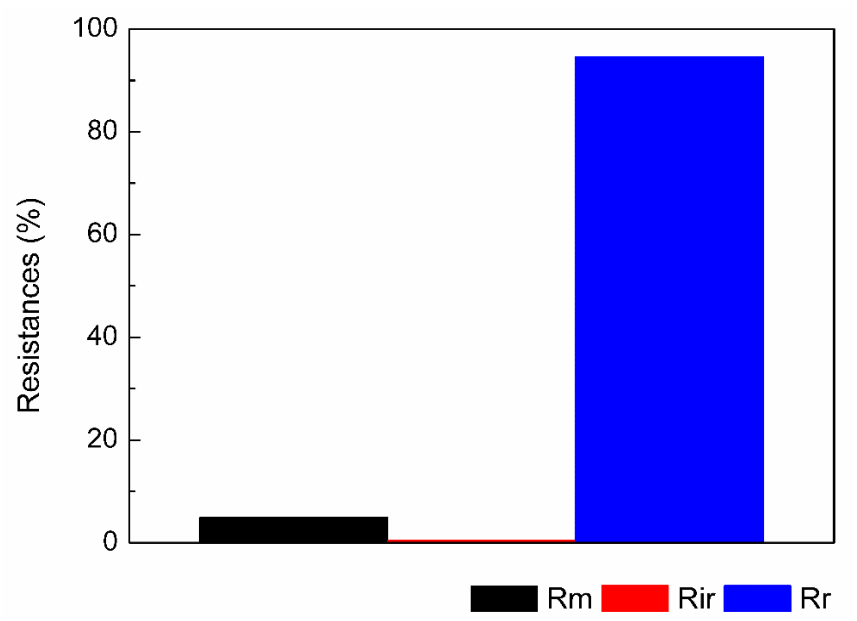

Figure 2. Percentages of reversible resistance $(\% \mathrm{Rr})$, membrane resistance $(\% \mathrm{Rm})$ and irreversible fouling resistance (\%Rir) in the permeate flow.

Benedetti et al. (2015) and Antunes (2014) studied the nanofiltration of tofu whey and pasteurized milk, respectively, and reported that the presence of substances with high molar mass (such as proteins) can influence membrane selectivity due to the adsorption and deposition of these compounds on the membrane surface. This deposition could change the charge of the membrane, affecting the permeation of negatively or positively charged compounds. Thus the loss of proteins in the present experiments may have occurred due to deposition on the membrane surface.

With respect to the lactose concentration, a value near to 2.0 fold was observed, despite the high retention values (> 99\%). According to Brião \& Tavares (2012b), membrane fouling leads to a major membrane rejection of lactose, justifying the high values visualized in the present study. Balannec et al. (2005) reported similar lactose rejection values when using a reverse osmosis membrane, and Yorgun et al. (2008) reported the same behaviour when comparing ultrafiltration, nanofiltration and reverse osmosis for whey treatment.

The lipids were the solutes showing the lowest retention values $(98.5 \%)$ and a concentration factor of around 1.6 fold. James et al. (2003) reported that despite their molecular size being higher than the membrane molar mass cut-off (MMC), lipid permeation is higher due to their nonpolar nature. According to Jönsson \& Trägårdh (1990), hydrophobic solutes are more easily adsorbed onto the membrane surface when compared to hydrophilic solutes. In addition, Brião \& Tavares (2012b) reported that the membranes had a density of pores with different sizes, so the passage of some of the lipids through the membrane could occur.

On analysing all the data presented above it can be seen that reverse osmosis is an interesting technology for milk concentration as a preliminary treatment in the dairy industry. However it is important to determine the flow decline behaviour since the resistances visualized throughout the process had a direct influence on the retention of the constituents and the process performance.

\subsection{Flow decline modelling}

Figure 3 shows the flow decline and the increase in soluble solids ( $\left.{ }^{\circ} \mathrm{brix}\right)$ concentration with time. 


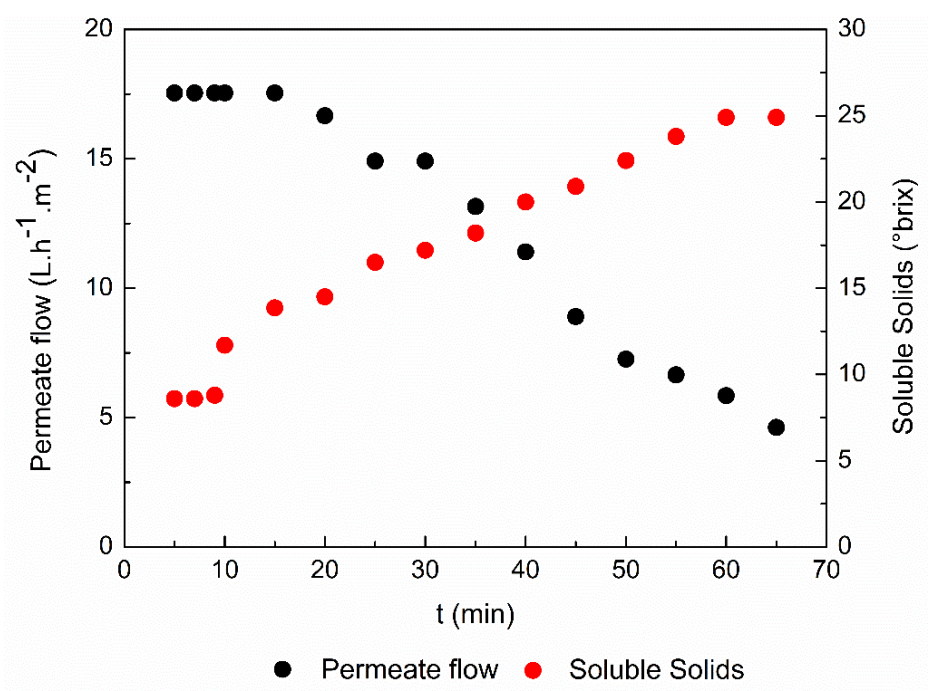

Figure 3. Flow decline behaviour (J) and soluble solids concentration ( ${ }^{\circ}$ brix) during the concentration of skim milk by reverse osmosis at 20 bar and $20^{\circ} \mathrm{C}$.

The decline in permeate flow at the beginning of the process is related to the solute concentration next to the membrane surface, known as concentration by polarization. In sequence, the slow decline in permeate flow occurred due to fouling and deposition of the compound on the membrane surface, resulting in the adsorption of some solutes and pore blocking (Cheryan, 1998; Marshall \& Daufin, 1995). When concentration by polarization occurs, it is the driving force for the diffusion of particles back to the bulk and creates a resistance to fluid flow. This phenomenon results in an increase in osmotic pressure of the solution, which can be observed from the increase in soluble solids in the concentrated fraction (Corbatón-Báguena et al., 2015).

The soluble solids increased around 3 fold and the flow reduced around 4 fold during the process. It can be said that the increase in concentration by polarization, with the consequent increase in the osmotic pressure, was the major factor responsible for the decline in flow. Jamal et al. (2004) confirmed this behaviour, reporting that at some critical point in the process, the osmotic pressure of the feed solution became so high and the flow declined significantly, such that the system had to be stopped. Thus, the increase in soluble solids results in an intensification of the solute concentration at the membrane-liquid interface and consequent increase in the osmotic pressure. With such an increase in the osmotic pressure, if there is no increment in the working pressure, the permeate flow will reduce, as observed in the present study.

The mechanisms involved in this process can promote higher concentrations of some constituents next to the membrane surface and, consequently, adhere to the surface or contribute to a gel layer, as described in the topic above. Furthermore, the decline in flow can be related to the scale up of the process, where the flow decline mechanisms need to be completely understood in order to reproduce the results on a larger scale.

Figure 2 shows the amounts of the resistances calculated (in percentage) involved in the reverse osmosis process of skim milk. Knowledge of these resistances is important since, in some cases, they can be reduced by changing the hydrodynamic conditions of the system. In addition, the resistances can change the selectivity of the membrane when a higher solute concentration is observed at the membrane surface.

The main resistance of the process was the reversible resistance, where the concentration by polarization was responsible for a major part. $\mathrm{R}_{\mathrm{r}}$ represented approximately $94 \%$ of the total resistance. According to the results obtained by Rezzadori et al. (2014), processes operating at pressures above 3 bar begin to be more susceptible to the deposition of solutes on the membrane surface, this deposition being related to the concentration by polarization layer. This resistance is directly associated with the increase in osmotic pressure of the feed solution, corroborating with the results described above. 
According to Kulozik \& Kessler (1990), besides protein deposition on the membrane surface, the increasing content of low molecular weight substances is the other main factor promoting high osmotic pressure values during the membrane process.

Membrane resistance represents around 5\% of the total resistance, a value related to mass transport through the reverse osmosis membrane, which is diffusion. Skim milk contains a considerable amount of proteins, which, according to Corbatón-Báguena et al. (2015), are active agents for membrane fouling, but considering that the membrane area was $5,7 \mathrm{~m}^{2}$, this amount of protein was not enough to cause a sharp decline in the first minutes of the process. The flow declined linearly with the increase in soluble solids content, and the increase in osmotic pressure caused by the deposition of these compounds on the membrane surface.

Based on this behaviour, the use of semi-empirical models which include a certain number of parameters with physical meaning seems to be appropriate to provide accurate predictions and to describe the fouling mechanisms (Corbatón-Báguena et al., 2015). In addition, different pore blocking mechanisms can be involved in membrane fouling (Verma \& Sarkar, 2015). The values obtained for the different pore blocking models are shown in Table 2. According to Torkamanzadeh et al. (2016), the goodness of fit of the permeation data to the Hermia model suggests that the complete pore blocking mechanism is dominant during skim milk filtration.

Table 2. Parameters obtained from the pore blocking models for the reverse osmosis of skim milk.

\begin{tabular}{ccc}
\hline & $\mathbf{k}$ & $\mathbf{R}^{\mathbf{2}}$ \\
\hline Complete pore blocking & -0.01961 & 0.93 \\
Standard pore blocking & 0.002863 & 0.88 \\
Filter cake layer & 0.000362 & 0.67 \\
\hline
\end{tabular}

$\mathrm{k}=$ resistance coefficient; $\mathrm{R}^{2}=$ determination coefficient.

The resistance coefficient $(\mathrm{k})$ was obtained considering a fixed value for the initial flow, and according to De Bruijn et al. (2002) and Razi et al. (2012) it is dependent on the resistance and concentration of filter cake layer and blocked surface, mostly being influenced by the system pressure.

The highest value for the coefficient $\mathrm{k}$ was obtained for the standard pore blocking model $\left(\mathrm{k}_{\mathrm{c}}\right)$. This parameter was related to the reduction in area and the initial number of pores per surface unit. Furthermore, this phenomenon always occurs in the non-steady-state condition, a behaviour visualized in the present study since the steady-state was not reached, because the process was interrupted when the system reached a volume reduction factor of three $(\mathrm{VRF}=3)$ (Almandoz et al., 2010).

With respect to the $\mathrm{R}^{2}$ value, the best fit was obtained for the complete pore blocking model $\left(\mathrm{R}^{2}=0.93\right)$. According to Almandoz et al. (2010) this model is related to the blocking of the pores by solutes that reach the membrane surface, occurring when the particle size is larger than that of the membrane pore (Salahi et al., 2010), and resulting in a decrease in the useful area of the membrane surface. The particle sizes of the major milk constituents are between 0.5 and $6000 \mathrm{~nm}$ for lactose and lipids, respectively (Fennema, 2000), all being retained by the RO membrane, corroborating with the results found.

Lin (2017), studying the effect of organic, biological and colloidal fouling on reverse osmosis, reported that standard pore blocking did not fit the models because the foulants were not able to enter the membrane and reduce the pore diameter. In addition, complete pore blocking was the model with the best fit, corroborating with the results found in the present study. The author justified this model as the best fit due to the deposition of foulants on each other on the membrane surface.

As described above, the pore blocking models can be associated with the permeate flow resistances. For reverse osmosis, the major resistance visualized was concentration by polarization and the best fit was complete pore blocking. The skim milk constituents are rejected by the membrane, increasing their concentration near the membrane. This behaviour leads to the solutes being deposited on the membrane surface by the complete block model. Thus the increase in concentration creates a diffusive flow, reducing 
the permeate flow and increasing the osmotic pressure of the solution (Chacón-Villalobos, 2005; Habert et al., 2006).

This phenomenon known as concentration by polarization is directly related to standard and complete pore blocking, confirming the present results (Mello et al., 2010). In addition, Salgado et al. (2013) reported that the pore blocking mechanisms are the first to appear, followed by the formation of a filter cake layer. The filter cake layer presented a $\mathrm{R}^{2}=0.67$, a behaviour which can be justified by the interruption of the process before the formation of the filter cake layer (Toyomoto \& Higuchi, 1992).

It is well known that pore blocking and filter cake formation occur simultaneously and that both mechanisms must be considered to explain membrane fouling (Corbatón-Báguena et al., 2015). The classical models are not able to describe the transition in fouling mechanisms that occurs during filtration, because they only evaluate a single mechanism at a time. The major advantage of the model proposed by Hermia is that it is simple and easy to implement for assessing the fouling mechanisms. However, due to its separate one-parameter mathematical expressions, it can lack accuracy when predicting the flow decline (Torkamanzadeh et al., 2016). The model developed by Ho \& Zydney (2000) combines pore blockage with filter cake formation and the results obtained using this model can be seen in Figure 4.

This model assumes that the particles are first deposited on the membrane surface, but are still permeable to permeate flow (Ho \& Zydney, 2000). These particles approach the membrane surface and then increase the osmotic pressure and reduce the permeate flow. Over time, the particles accumulate on top of each other and the filter cake layer grows.

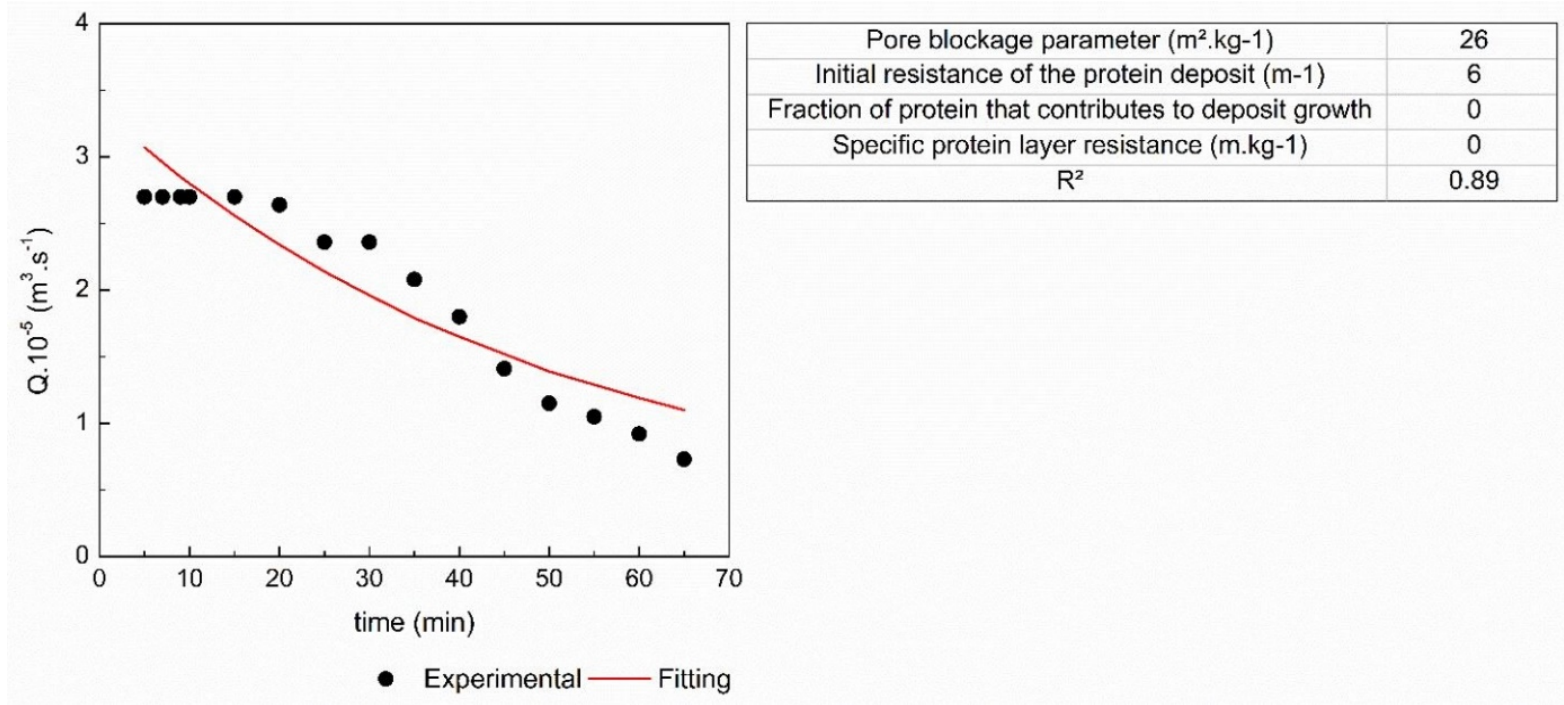

Figure 4. Fitted data of the parameters of the Ho \& Zydney (2000) model for prediction of the permeate flow during the concentration of skim milk by reverse osmosis.

In the present study, it was observed that the fraction of the total protein that contributed to growth of the filter cake layer ( $\left.f^{\prime}\right)$ and the resistance of the specific protein layer ( $\left.\mathrm{R}^{\prime}\right)$ were zero, corroborating with the results presented previously, where the osmotic pressure and the concentration by polarization layer were the major factors responsible for the flow decline.

The second term of this model is related to the growth of the filter cake layer, the low values obtained for these parameters demonstrating that there was a small or zero development of the filter cake layer, the flow reduction being associated with the concentration of solutes next to the membrane surface and the increase in osmotic pressure. This behaviour can be explained by the interruption of the process when the VRF $=3$ was reached, preventing the development of the filter cake layer. 


\section{Conclusion}

The objectives of this study were to evaluate the use of reverse osmosis in the concentration of skim milk and to provide a comprehensive description of the flow decline mechanisms involved in the process.

By the mathematical modelling of the flow decline it was possible to conclude that the flow decline was mainly caused by the combination of an increase in the osmotic pressure and the deposition of solutes on the membrane surface.

With respect to the efficiency of reverse osmosis in the concentration of skim milk, it was observed that the $\%$ retention of all the constituents was over $98 \%$. These high values prove the potential of this technology for use as a pre-concentration step, aiming to obtain a product with the sensory and nutritional qualities preserved with lower production costs.

\section{Acknowledgements}

The authors are grateful for the financial support and scholarships provided by CNPq - Brazil and CAPES - Brazil.

\section{References}

Almandoz, C., Pagliero, C., Ochoa, A., \& Marchese, J. (2010). Corn syrup clarification by microfiltration with ceramic membranes. Journal of Membrane Science, 363(1-2), 87-95. http://dx.doi.org/10.1016/j.memsci.2010.07.017

Antunes, V. C. (2014). Uso de microfiltração para melhoria da qualidade e extensão da vida de prateleira de leite pasteurizado. Brazilian Journal of Food Technology, 17(1), 75-86. http://dx.doi.org/10.1590/bjtt.2014.011

Association of Official Analytical Chemists - AOAC. (1990). Official methods of analysis (15th ed.). Virginia: AOAC.

Balannec, B., Vourch, M., Rabiller-Baudry, M., \& Chaufer, B. (2005). Comparative study of different nanofiltration and reverse osmosis membranes for dairy effluent treatment by dead-end filtration. Separation and Purification Technology, 42(2), $195-200$. http://dx.doi.org/10.1016/j.seppur.2004.07.013

Balde, A., \& Aïder, M. (2017). Effect of cryoconcentration, reverse osmosis and vacuum evaporation as concentration step of skim milk prior to drying on the powder properties. Powder Technology, 319, 463-471.

http://dx.doi.org/10.1016/j.powtec.2017.07.016

Benedetti, S., Prudêncio, E. S., Nunes, G. L., Guizoni, K., Fogaça, L. A., \& Petrus, J. C. C. (2015). Antioxidant properties of tofu whey concentrate by freeze concentration and nanofiltration processes. Journal of Food Engineering, 160, 49-55.

http://dx.doi.org/10.1016/j.jfoodeng.2015.03.021

Brião, V. B., \& Tavares, C. R. G. (2012a). Pore blocking mechanism for the recovery of milk solids from dairy wastewater by ultrafiltration. Brazilian Journal of Chemical Engineering, 29(2), 393-407. http://dx.doi.org/10.1590/S0104-66322012000200019 Brião, V. B., \& Tavares, C. R. G. (2012b). Nota Cientifica. Brazilian Journal of Food Technology, 15(4), 352-362. http://dx.doi.org/10.1590/S1981-67232012005000028

Chacón-Villalobos, A. (2005). Tecnologias de membranas en la agroindustria lactea. Agronomía Mesoamericana, 17(2), 243264. http://dx.doi.org/10.15517/am.v17i2.5164

Cheryan, M. (1998). Ultrafiltration and microfiltration handbook (2nd ed.). Lancaster: Technomic Publishing Company. http://dx.doi.org/10.1201/9781482278743.

Corbatón-Báguena, M., Álvarez-Blanco, S., \& Vincent-Vela, M. (2015). Fouling mechanisms of ultrafiltration membranes fouled with whey model solutions. Desalination, 360, 87-96. http://dx.doi.org/10.1016/j.desal.2015.01.019

Daufin, G., Scudier, J. P., Carrere, H., Berrot, S., Fillaudeau, L., \& Decloux, M. (2001). Recent and emergin applications of membrane processes in the food and dairy industry. Institution of Chemical Engineers, 79, 89-102.

De Bruijn, J., Venegas, A., \& Borquez, R. (2002). Influence of crossflow ultrafiltration on membrane fouling and apple juice quality. Desalination, 148(1-3), 131-136. http://dx.doi.org/10.1016/S0011-9164(02)00666-5

Depping, V., Grunow, M., van Middelaar, C., \& Dumpler, J. (2017). Integrating environmental impact assessment into new product development and processing-technology selection: Milk concentrates as substitutes for milk powders. Journal of Cleaner Production, 149, 1-10. http://dx.doi.org/10.1016/j.jclepro.2017.02.070

Fennema, O. R. (2000). Química de los alimentos (2nd ed.). Zaragoza: Acribia.

Field, R. W., Wu, D., Howell, J. A., \& Gupta, B. B. (1995). Critical flux concept for microfiltration fouling. Journal of Membrane Science, 100(3), 259-272. http://dx.doi.org/10.1016/0376-7388(94)00265-Z

Habert, A. C., Borges, C. P., \& Nobrega, R. (2006). Processos de separação com membranas. Rio de Janeiro: E-papers Serviços Editoriais.

Hermia, J. (1982). Constant pressure blocking filtration laws: Application to power-law non-newtonian fluids. Icheme, 60, 183187.

Ho, C., \& Zydney, A. L. (2000). A combined pore blockage and cake filtration model for protein fouling during microfiltration. Journal of Colloid and Interface Science, 232(2), 389-399. PMid:11097775. http://dx.doi.org/10.1006/jcis.2000.7231 
Instituto Adolfo Lutz - IAL. (2008). Métodos físico-quimico para análise de alimentos (4th ed.). São Paulo: IAL.

Jamal, K., Khan, M. A., \& Kamil, M. (2004). Mathematical modeling of reverse osmosis systems. Desalination, 160(1), $29-42$. http://dx.doi.org/10.1016/S0011-9164(04)90015-X

James, B. J., Jyng, Y., \& Cheng, X. D. (2003). Membrane fouling during filtration of milk: A microstructural study. Journal of Food Engineering, 60(4), 431-437. http://dx.doi.org/10.1016/S0260-8774(03)00066-9

Jönsson, A., \& Trägårdh, G. (1990). Ultrafiltration applications. Desalination, 77, 135-179. http://dx.doi.org/10.1016/00119164(90)85024-5

Kulozik, U., \& Kessler, H. G. (1990). The kinetics of the formation of a deposited layer during the reverse osmosis of skim milk. Journal of Membrane Science, 54(1-2), 13-27. http://dx.doi.org/10.1016/S0376-7388(00)82067-0

Lin, Y. L. (2017). Effects of organic, biological and colloidal fouling on the removal of pharmaceuticals and personal care products by nanofiltration and reverse osmosis membranes. Journal of Membrane Science, 542, 342-351.

http://dx.doi.org/10.1016/j.memsci.2017.08.023

Liu, D. Z., Dunstan, D. E., \& Martin, G. J. O. (2012). Evaporative concentration of skimmed milk: Effect on casein micelle hydration, composition, and size. Food Chemistry, 134(3), 1446-1452. PMid:25005965. http://dx.doi.org/10.1016/j.foodchem.2012.03.053

Marshall, A. D., \& Daufin, G. (1995). Physico-chemical aspects of membrane fouling by dairyfluids. In H. C. Van der Horst (Ed.), Fouling and cleaning in pressure driven membrane processes (pp. 8-35). Brussels: International Dairy Federation.

Mello, B. C. B. S. (2012). Extração de própolis em meio aquoso e concentração dos extratos por nanofiltração. Campinas: Universidade Estadual de Campinas.

Mello, B. C. B. S., Petrus, J. C. C., \& Hubinger, M. D. (2010). Desempenho do processo de concentração de extratos de própolis por nanofiltração. Food Science and Technology, 30(1), 166-172. http://dx.doi.org/10.1590/S010120612010000100025

Mendes, P. N., Furtado, M. A. M., \& Perrone, Í. T. (2012). Osmose reversa na produção de leite condensado: Uma possibilidade tecnológica. Revista do Instituto de Latícinios Cândido Tostes, 67(388), 68-76. http://dx.doi.org/10.5935/22386416.20120067

Meyer, P., Mayer, A., \& Kulozik, U. (2015). High concentration of skim milk proteins by ultrafiltration: Characterisation of a dynamic membrane system with a rotating membrane in comparison with a spiral wound membrane. International Dairy Journal, 51, 75-83. http://dx.doi.org/10.1016/j.idairyj.2015.07.010

Miller, G. L. (1959). Use of dinitrosalicylic acid reagent for determination of reducing sugar. Analytical Chemistry, 31(3), 426428. http://dx.doi.org/10.1021/ac60147a030

Razi, B., Aroujalian, A., \& Fathizadeh, M. (2012). Modeling of fouling layer deposition in cross-flow microfiltration during tomato juice clarification. Food and Bioproducts Processing, 90(4), 841-848. http://dx.doi.org/10.1016/j.fbp.2012.05.004

Rezzadori, K., Serpa, L., Penha, F. M., Petrus, R. R., \& Petrus, J. C. C. (2014). Crossflow microfiltration of sugarcane juice: Effects of processing conditions and juice quality. Food Science and Technology, 34(1), 210-217. http://dx.doi.org/10.1590/S0101-20612014000100030

Said, M., Ahmad, A., Mohammad, A. W., Nor, M. T. M., \& Sheikh Abdullah, S. R. (2015). Blocking mechanism of PES membrane during ultrafiltration of POME. Journal of Industrial and Engineering Chemistry, 21, 182-188. http://dx.doi.org/10.1016/j.jiec.2014.02.023

Salahi, A., Abbasi, M., \& Mohammadi, T. (2010). Permeate flux decline during UF of oily wastewater: Experimental and modeling. Desalination, 251(1-3), 153-160. http://dx.doi.org/10.1016/j.desal.2009.08.006

Salgado, C., Palacio, L., Carmona, F. J., Hernández, A., \& Prádanos, P. (2013). Influence of low and high molecular weight compounds on the permeate flux decline in nanofiltration of red grape must. Desalination, $315,124-134$. http://dx.doi.org/10.1016/j.desal.2012.09.032

Tamime, A. Y., \& Robinson, R. K. (2007). Tamime and Robinson's yoghurt. Cambridge: Woodhead Publishing. http://dx.doi.org/10.1533/9781845692612.

Torkamanzadeh, M., Jahanshahi, M., Peyravi, M., \& Shokuhi Rad, A. (2016). Comparative experimental study on fouling mechanisms in nano-porous membrane: Cheese whey ultrafiltration as a case study. Water Science and Technology, 74(12), 2737-2750. PMid:27997385. http://dx.doi.org/10.2166/wst.2016.352

Toyomoto, K., \& Higuchi, A. (1992). Microfiltration and ultrafiltration. New York: Marcel Dekker.

Verma, S. P., \& Sarkar, B. (2015). Analysis of flux decline during ultrafiltration of apple juice in a batch cell. Food and Bioproducts Processing, 94, 147-157. http://dx.doi.org/10.1016/j.fbp.2015.03.002

Wenten, I. G., \& Khoiruddin, (2016). Reverse osmosis applications: Prospect and challenges. Desalination, 391, 112-125. http://dx.doi.org/10.1016/j.desal.2015.12.011

Yorgun, M. S., Balcioglu, I. A., \& Saygin, O. (2008). Performance comparison of ultrafiltration, nanofiltration and reverse osmosis on whey treatment. Desalination, 229(1-3), 204-216. http://dx.doi.org/10.1016/j.desal.2007.09.008 


\section{Nomenclature}

A Membrane area, $\mathrm{m}^{2}$

C Bulk protein concentration, $\mathrm{g} \mathrm{L}^{-1}$

$f^{\prime}$ Fraction of the total protein that contributes to depositing growth, dimensionless

J Permeate flow, $\mathrm{L} \mathrm{h}^{-1} \mathrm{~m}^{-2}$

$\mathrm{J}^{*}$ Critical flow in the constant flow stage, $\mathrm{L} \mathrm{h}^{-1} \mathrm{~m}^{-2}$

$\mathrm{k}$ Constant related to the pore blocking mechanisms, dimensionless

$\mathrm{n}$ Index related to the pore blocking mechanisms, dimensionless

Q Volumetric flow rate, $\mathrm{m}^{3} \mathrm{~s}^{-1}$

$\mathrm{Q}_{0}$ Initial volumetric flow rate, $\mathrm{m}^{3} \mathrm{~s}^{-1}$

$\mathrm{R}_{\text {ir }}$ Irreversible resistance, $\mathrm{m}^{-1}$

$\mathrm{R}_{\mathrm{m}}$ Membrane resistance, $\mathrm{m}^{-1}$

$\mathrm{R}_{\mathrm{p}}$ Resistance of the protein deposit, $\mathrm{m}^{-1}$

$\mathrm{R}_{\mathrm{p} 0}$ Initial resistance of the protein deposit, $\mathrm{m}^{-1}$

$\mathrm{R}_{\mathrm{r}}$ Reversible resistance, $\mathrm{m}^{-1}$

$\mathrm{R}_{\mathrm{t}}$ Total resistance, $\mathrm{m}^{-1}$

$\mathrm{R}^{\prime}$ Specific protein layer resistance, $\mathrm{m} \mathrm{kg}^{-1}$

T Filtration time, $\mathrm{s}$

$\alpha$ Pore blockage parameter, $\mathrm{m}^{2} \mathrm{~kg}^{-1}$

$\Delta \mathrm{P}$ Transmembrane pressure, $\mathrm{Pa}$

$\mu$ Permeate viscosity, Pa s 